Soil Science and Agricultural Engineering

\title{
QUALITY OF SURFACE WATER IN SOME SELECTED DRAINS AND
} CANALS IN FAYOUM GOVERNORATE

\author{
Mahmoud I.T. Ghieth ${ }^{1 *}$, K.G. Soliman ${ }^{2}$ and M.S. Abu-Hashim ${ }^{2}$ \\ 1. Hydraulics Res. Inst., National Water Research Center, Egypt \\ 2. Soil Sci. Dept., Fac. Agric., Zagazig Univ., Egypt
}

Received: 06/08/2019; Accepted: 15/09/2019

\begin{abstract}
A Total of 36 water samples were collected from 3 irrigation and drainage canals in Fayoum Governorate, Egypt, to identify the quality for irrigation. Site 1; Bahr Wahby Canal, Site 2; Batss drain and Site 3; El Gharaq drain. Measurements included pH, EC soluble ions, and heavy metals during 12 months (one sample each month for each site) from April 2016 to March 2017. The $\mathrm{pH}$ varied from 7.00 to 9.32 , while EC average for sites 1, 2, and 3 were 2.13, 2.20, and $3.85 \mathrm{dSm}^{-1}$, respectively. Sodium adsorption ratio (SAR) values were 4.88, 4.98 and 7.53 for sites 1,2 , and 3, respectively. Water quality for site 1 and 2 was $\mathrm{C}_{3} \mathrm{~S}_{2}$ (high salinity and medium sodicity hazards), while for site 3 they were $\mathrm{C}_{4} \mathrm{~S}_{2}$ (very high salinity and medium sodicity hazards) and could be used for crops which are tolerant to salinity. All heavy elements at the three sites were below the permissible limits. Water measurements and assessment are important in determining their quality.
\end{abstract}

Key words: Water quality, salinity, drains, agriculture.

\section{INTRODUCTION}

Egypt is located in a dry climate zone where rainfall is scarce and the desert covers most of the land. In addition to its fixed annual Nile water quota of 55.5 billion $\mathrm{m}^{3}(\mathrm{BCM})$, a deep groundwater reservoir, which is not renewable, may be used at a rate of 2.7 billion $\mathrm{m}^{3}$ (BCM) over a period of 100 years (Allam and Allam, 2007). The water shortage is a main constraint and a major limiting factor facing the country.

In water scarce countries depending on external water supply, such as Egypt, water distribution to different users is of paramount importance. For its water resources, Egypt is depending mainly on the supply of fresh water through the Rive Nile which originate in middle Africa. In addition to the Nile water, groundwater from the Nubian aquifer and rainfall along the Northern Egyptian coast represent additional sources. The expanding population of Egypt creates an Evergrowing pressure on the government to provide water for new land reclamation. Public water

\footnotetext{
*Corresponding author: Tel. : +2010666642399

E-mail address: ghieth_mmath@yahoo.com
}

supply and industrial water requirements are increasing at the expense of agricultural water use.

All such developments resulted adopting a strategy to reuse drainage water for irrigation which complicates management and planning of water distribution, but certainly is a fast and cheap way to improve the overall efficiency of water use in the Nile Delta.

The strong need for more effective development and management of the limited resources of water, to meet the population growth represent a major challenge facing Egypt. Fresh water resources have faced a crisis worldwide for the last decades (MWRI, 2013). This is revealed in numerous challenges including increasing scarcity of fresh water, lack of accessibility to adequate clean drinking water, deterioration of water quality, and inadequate financial resources allocation.

Agricultural is the largest water consumer sector in Egypt as it uses about $80 \%$ of total 
water. The cultivated area increased from 2.44 million ha in 1980 to 3.61 million ha (8.6 million faddans) in 2010 despite losses of substantial areas of agricultural lands as a result of urban expansion (MWRI, 2013). As a result of the increase in cultivated area, water use for agriculture increased from $30 \mathrm{BCM}$ per annum in 1950 to $67 \mathrm{BCM}$ in 2010. In old lands in the Nile Valley and the Delta (6 million faddans) the surface irrigation system prevails with its low conveyance efficiency.

Fayoum is one of the governorates of Egypt in the middle of the country, (Fig. 1). Its capital is the city of Fayoum. It has an area of 6,068.70 $\mathrm{km}^{2}$ and a population of $3,170,150$ according to the census of 2015, (CAPMAS, 2016), with six districts (Fayoum, Sonors, Ebshwy, Etsa, Tamia, and Yusuf El-Sedeek), (EEAA, 2008).

Fayoum has particular geographic and topographic features as the environment is a mix of agricultural, desert and coastal nature.

The surface water in Fayoum from Ibrahimiya canal which branches from the Nile River at Assuit. At Dairut regulators, $284 \mathrm{~km}$ upstream of Lahun regulator at Fayoum, flow is diverted from Ibrahimiya canal to Bahr Yusuf. Fayoum is at the tail of Bahr Yusuf. The upstream Governorates of Minia and Beni Suef are supplied with water first, and then comes Fayoum.

The lag time of water from Ibrahimiya regulator at Assuit to Lahun regulator is five days. The average water quota of the Fayoum is $3.05(\mathrm{BCM}) \mathrm{y}^{-1}$ annually. The geomorphologic formations of the Fayoum basin contain no groundwater aquifers except amount of 0.40 BCM.year from shallow aquifer.

Fig. 2 shows the distribution of irrigation network in Fayoum. Fig. 3 shows the network of drains in Fayoum Governorate (MWRI, 2013).

\section{MATERIALS AND METHODS}

\section{Water Sampling}

A Total of 36 water samples were collected from 3 sources of irrigation and drainage canals in Fayoum Governorate, Egypt. Source 1; Bahr Wahby Canal, Source 2; Batss drain and Source
3; El Gharaq drain. Measurements included $\mathrm{pH}$, electrical conductivity (EC), soluble ions and heavy metals were carried during 12 months (One sample each month for each site) from April 2016 to March 2017. Water samples were taken monthly from April 2016 to March 2017. Fig. 4 show the study area and sampling sources. Longitude and latitude of 3 sources are presented in Table 1.

Samples were collected at a depth about below in surface $60 \mathrm{~cm}$ to ensure that the sampled water was represented. The water samples were collected in polyethylene bottles. Samples for heavy metal analysis were collected in acidwashed polyethylene bottles and preserved by Toluene (Methylbenzen- C6H5CH3) $(\mathrm{pH}<2)$ at the site. Samples were immediately filtered and subjected to chemical analyses. Each of $\mathrm{pH}$ and $\mathrm{EC}$ were measured in site using precision $\mathrm{pH}$ meter (PHS 2C) T-Bota Scietech, Nanjong, China) and EC meter (DDSJ 308A) Biocotek, Nanjbo, China) at $25^{\circ} \mathrm{C}$ then kept under refrigerated conditions (Cooling boxes). Samples were delivered within $48 \mathrm{hr}$., to the laboratory and stored in dark at $4{ }^{\circ} \mathrm{C}$ until they were analyzed.

\section{Water Analyses}

Water samples were analysed for $\mathrm{pH}, \mathrm{EC}$, sodium $\left(\mathrm{Na}^{+}\right)$, sulphate $\left(\mathrm{SO}_{4}{ }^{2-}\right)$, ammonium $\left(\mathrm{NH}_{4}{ }^{+}\right)$, potassium $\left(\mathrm{K}^{+}\right)$, chloride $\left(\mathrm{Cl}^{-}\right)$, bicarbonate $\left(\mathrm{HCO}_{3}^{-}\right)$, nitrate $\left(\mathrm{NO}_{3}^{-}\right)$, calcium $\left(\mathrm{Ca}^{2+}\right)$, manganesium $\left(\mathrm{Mg}^{2+}\right)$ and heavy metals [cobalt $(\mathrm{Co})$, iron $(\mathrm{Fe})$, lead $(\mathrm{Pb})$, cadmium $(\mathrm{Cd})$, copper $(\mathrm{Cu})$, zinc $(\mathrm{Zn})$, manganese $(\mathrm{Mn})$, and Nickel (Ni)]. All samples were analysed following methods cited in USDA (1954). Sulphate was calculated by difference. Boron was determined by the curcumin method (Jackson, 1958). Heavy metals were measured using Atomic Absorption Spectrophotometer (Perkin-Elmer, Model 290B, Norwalk, CT, Perkin Elmer 3300).

\section{Quality Indices}

Using the above chemical analyses, the following quality indices were determined:

Salinity was measured in terms of electric conductivity (EC) measured as $\mathrm{dSm}^{-1}$. Soluble Sodium percentage (SSP) was calculated as:

$$
\mathrm{SSP}=\frac{\mathrm{Na}}{\sum \text { Cations }} \times 100
$$




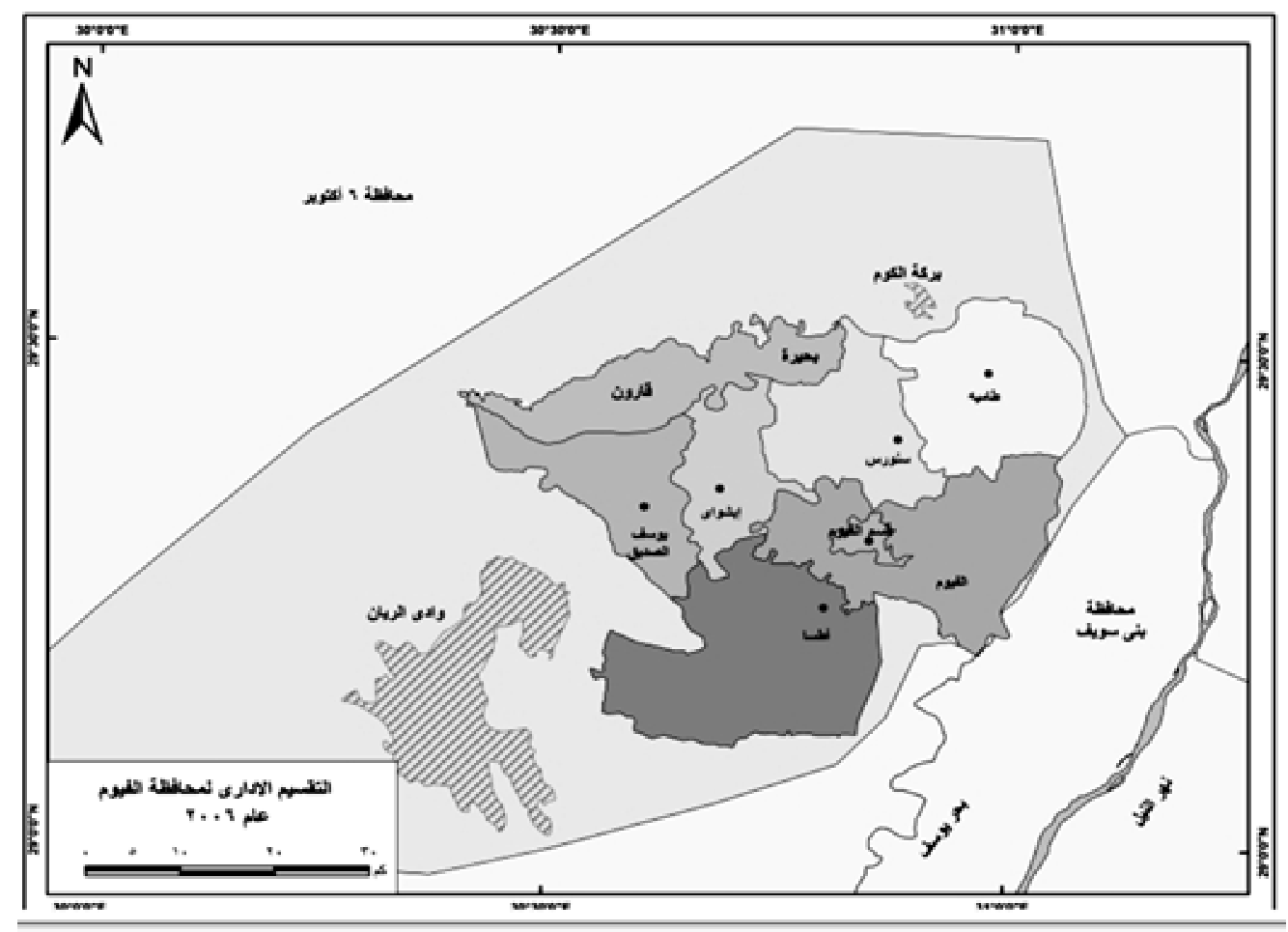

Fig. 1. Administrative division for Fayoum Governorate, (Source: Fayoum Irrigation Dept.)

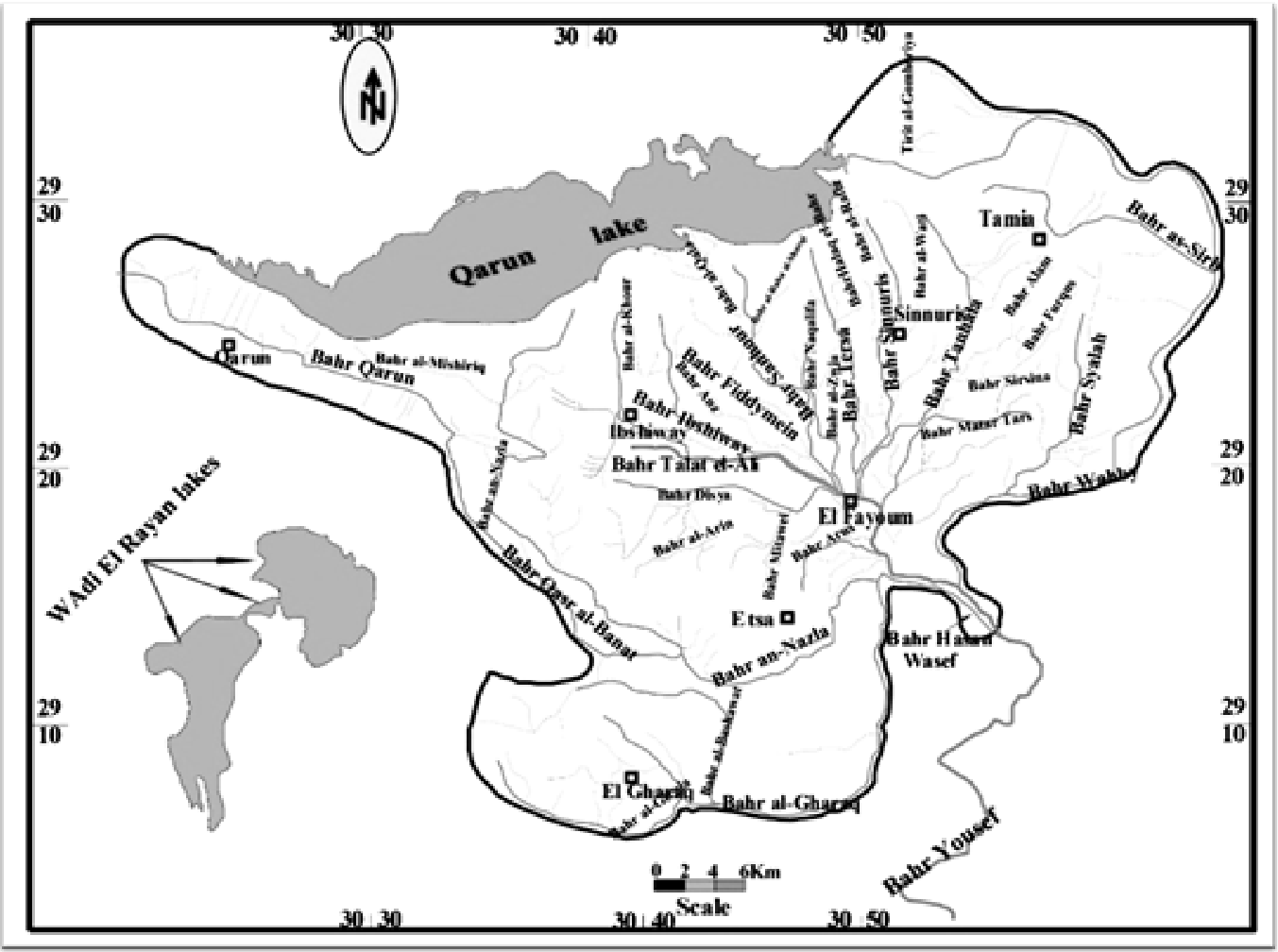

Fig. 2. Irrigation network of Fayoum Governorate, (Source: Fayoum Irrigation Dept.) 


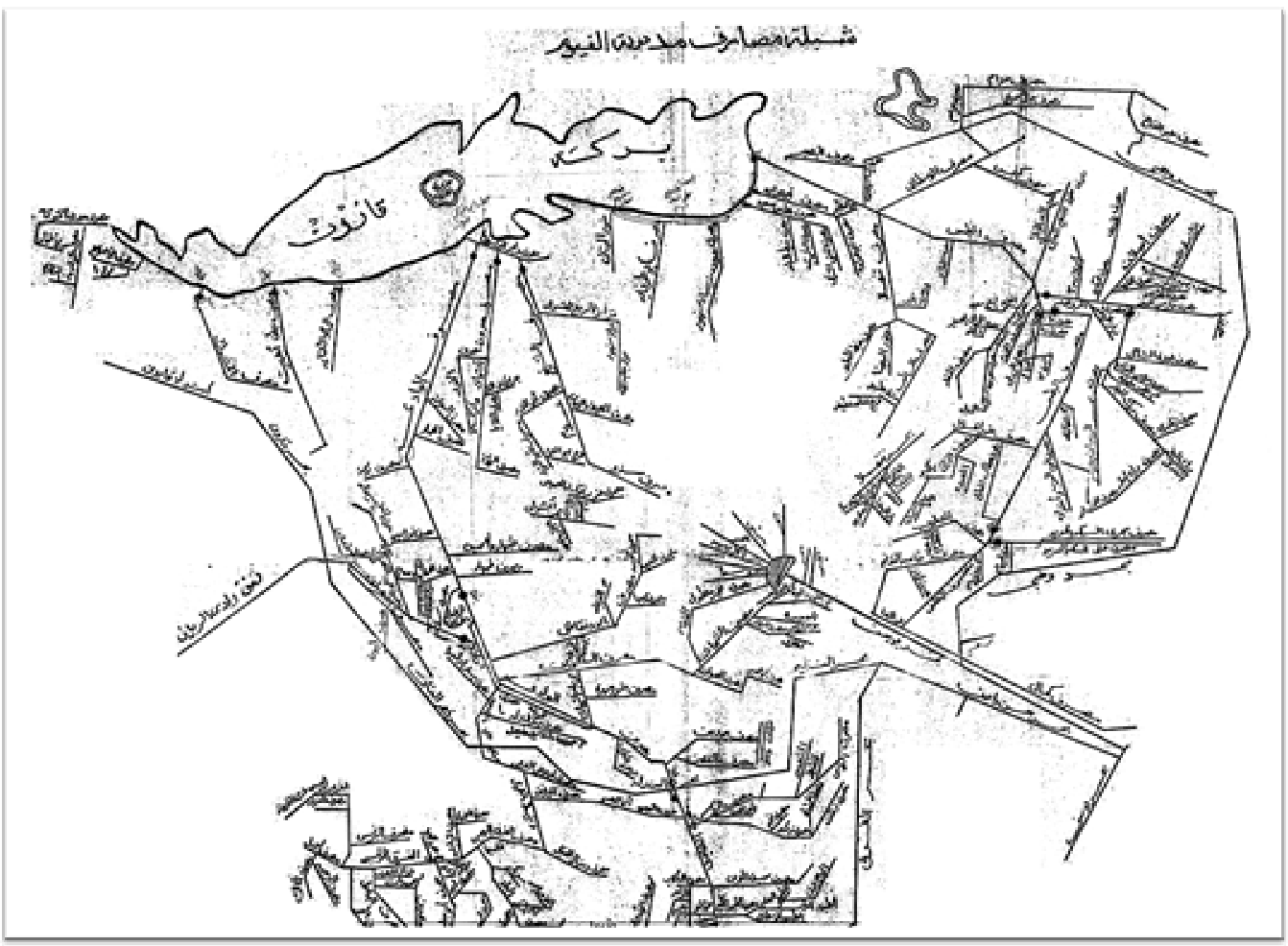

Fig. 3. Schematic Diagram for Drains Network in Fayoum Governorate, (Source: Fayoum Irrigation Dept.)

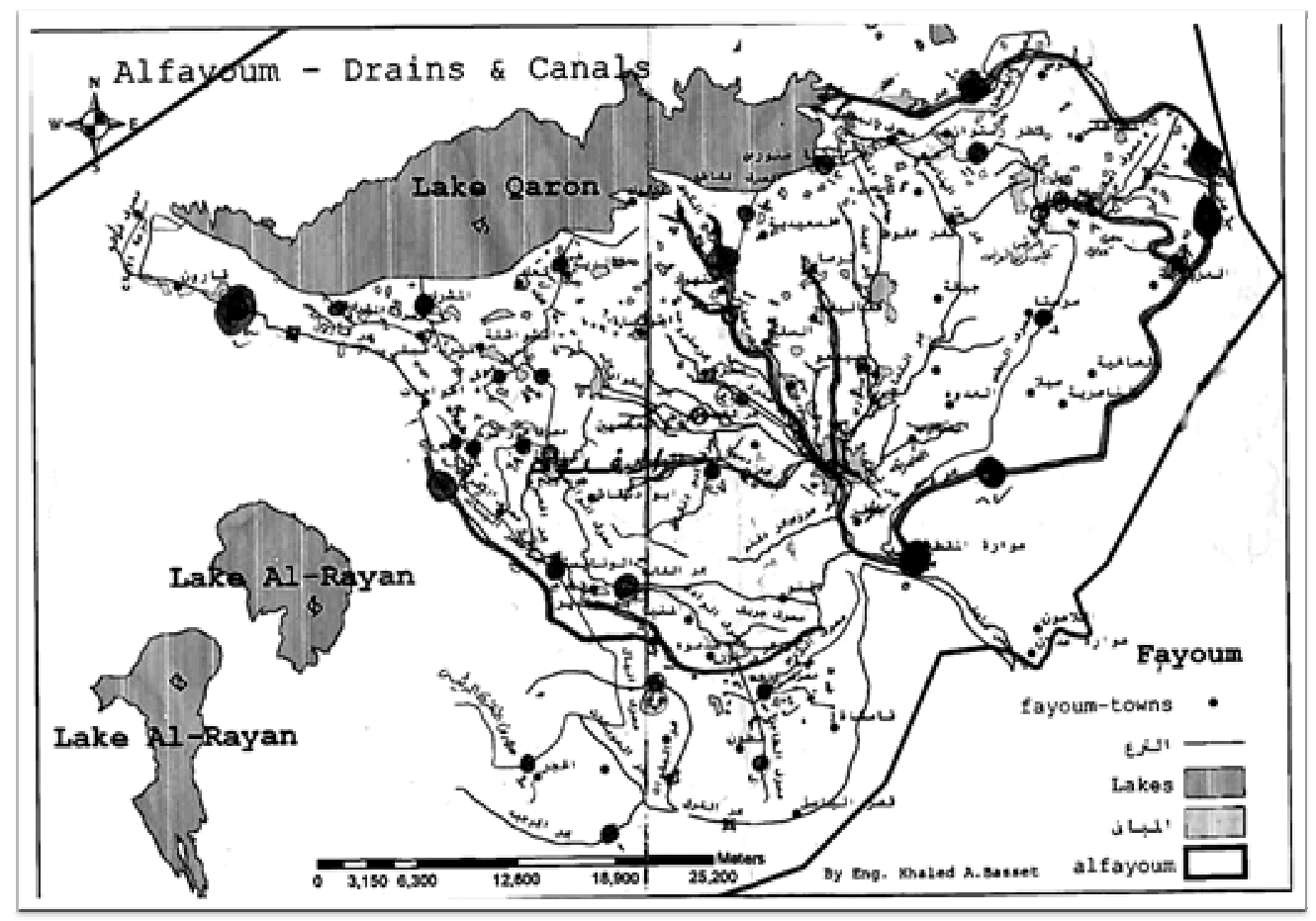

Fig. 4. Locations of Drainage Water Sampling Taken form Batss, El Gharaq Drain and Bahr Wahby Canal 
Table 1. The location of drain and canal water samples

\begin{tabular}{cccc}
\hline Sample No. & X & Y & Description \\
\hline 1 & 3259278 & 313925 & Bahr Wahby canal \\
2 & 3262297 & 302908 & Batss drain \\
3 & 3226794 & 272281 & El Gharq drain \\
\hline
\end{tabular}

Where:

Ions are expressed as $\mathrm{mmol}_{\mathrm{c}} \mathrm{L}^{-1}(1)$

Sodium adsorption ratio (SAR) was calculated as:

$$
\mathrm{SAR}=\frac{\mathrm{Na}^{+}}{\sqrt{\mathrm{Ca}^{++}+\mathrm{Mg}^{++} / 2}}
$$

Where:

Ions are expressed as $\mathrm{mmol}_{\mathrm{C}} \mathrm{L}^{-1}$

Adjusted Sodium Adsorption Ratio (adj. SAR) calculated according to the following equation (Ayers and Westcot, 1976):

Adj.SAR $=$ SAR $\left[1+\left(8.4-\mathrm{pH}_{\mathrm{c}}\right)\right]$

$\mathrm{pH}_{\mathrm{c}}=\left(\mathrm{PK}_{2}^{\prime}-\mathrm{PK}_{\mathrm{c}}^{\prime}\right)+\mathrm{p}\left(\mathrm{Ca}^{2+}+\mathrm{Mg}^{2+}\right)+\mathrm{p}(\mathrm{Alk})$

Adjusted sodium hazard (adj. ${ }^{\mathrm{R}} \mathrm{Na}$ ) was as follows:

$$
\text { Adj. }{ }^{\mathrm{R}} \mathrm{Na}=\frac{\mathrm{Na}^{+}}{\sqrt{\mathrm{Ca}_{\times}^{2+}+\mathrm{Mg}^{2+} / 2}}(\text { Suarez, 1981) (5) }
$$

Where:

$\mathrm{Ca}_{\mathrm{x}}$ value modified according to salinity water, its $\mathrm{HCO}_{3} / \mathrm{Ca}$ ratio and the estimated partial pressure of $\mathrm{CO}_{2}\left(\mathrm{PCO}_{2}=0.0007\right)$ atmospheres, and $\mathrm{Mg}$ in water. The $\mathrm{Ca}_{\mathrm{x}}$, value represents $\mathrm{Ca}$ expected to remain in a solution of soil water at equilibrium. The obtained adj. ${ }^{\mathrm{R}} \mathrm{Na}$ is used in place of the SAR to evaluate $\mathrm{Na}$ hazard which can cause infiltration problems if water is used for irrigation.

Estimated exchangeable sodium percent (ESP) expected in soil irrigated with water was calculated as follows (USDA, 1954), using the SAR of irrigation water.

$$
\mathrm{ESP}=\frac{100(-0.0126+0.001745 \mathrm{SAR})}{1+(-0.0126+0.001745 \mathrm{SAR})}
$$

The permeability index (PI) was calculated as follows (Doneen, 1964):

$$
\mathrm{PI}=\frac{\mathrm{Na}^{+}+\sqrt{\mathrm{HCO}_{3}^{-} \times 100}}{\mathrm{Na}^{+}+\mathrm{Ca}^{2}+\mathrm{Mg}^{2+}}(7)
$$

\section{RESULTS AND DISCUSSION}

As for the results of water chemistry and its suitability for irrigation, water quality were evaluated on basis of salinity, sodicity, residual sodium carbonate, boron, heavy metal and nitrogen contents. Tables 2, 3, 4, 5, 6 and 7 show the chemical analysis of water samples of the studied sites in Fayoum Governorate that measured monthly from April 2016 to March 2017.

\section{pH}

Water were slightly alkaline with $\mathrm{pH}$ ranging between 7.00 to 9.32 (Tables 2, 3 and 4). $\mathrm{pH}$ of Locations 1, 2 and 3 were 7.87, 7.96 and 7.79, respectively. Waters of locations 1,2 and 3 had slightly high $\mathrm{pH}$. In general, such values are within the normal range of the FAO guidelines for water quality (Ayers and Westcot, 1976). Quality based on concepts introduced by US salinity Laboratories such as $\mathrm{pH}$ and adjusted sodium adsorption ration (SAR), Gupta (1979a) suggested five classes based on salinity and sodicity hazard as well as boron. FAO (2002) reported that $\mathrm{pH}$ of some wastewaters in Egypt did not vary widely from that of the Nile water, and ranged from 7.29 to 7.40. El-Sherbieny $\boldsymbol{e t}$ al. (1998) showed that $50 \%$ of the agricultural drainage waters had $\mathrm{pH}$ of 7.6 to 8.4. (Shaban, 1998) stated that the $\mathrm{pH}$ of irrigation water in Egypt varied between 8.22 
Table 2. Mean values of dominant elements, some calculated indices, and classification for water samples collected from Bahr Wahby canal from April 2016 to March 2017

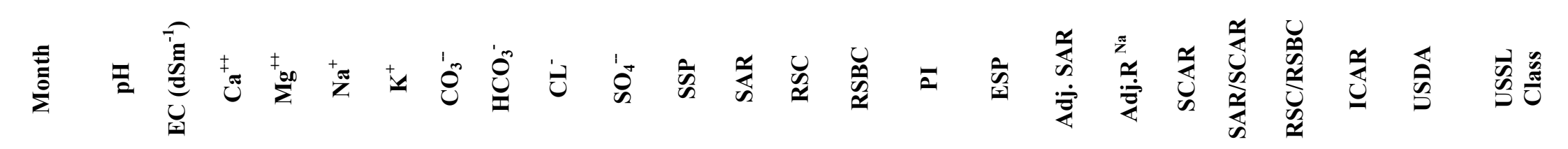

\begin{tabular}{lllllllllllllllllllllllll}
\hline Apr.2016 & 7.98 & 1.86 & 4.55 & 2.50 & 11.09 & 0.64 & 0.00 & 5.28 & 7.90 & 5.61 & 59.03 & 5.90 & -1.78 & 0.72 & 73.77 & 7.52 & 12.58 & 7.38 & 5.20 & 1.22 & 17.19 & $\mathrm{C}_{2} \mathrm{~S}_{0}$ & $\mathrm{C}_{3} \mathrm{~S}_{2}$ & $\mathrm{Acceptable}$
\end{tabular}

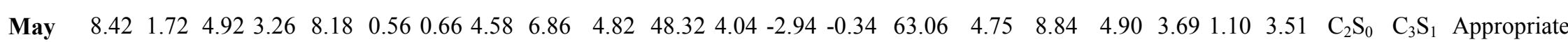

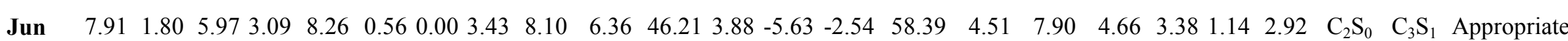

$\begin{array}{lllllllllllllllllllllllllllllllll}\text { July } & 7.00 & 1.83 & 5.90 & 3.41 & 8.70 & 0.26 & 0.00 & 5.45 & 7.33 & 5.48 & 47.62 & 4.03 & -3.86 & -0.46 & 61.26 & 4.73 & 9.03 & 5.13 & 3.58 & 1.13 & 5.68 & \mathrm{C}_{2} \mathrm{~S}_{0} & \mathrm{C}_{3} \mathrm{~S}_{1} & \mathrm{Appropriate}\end{array}$

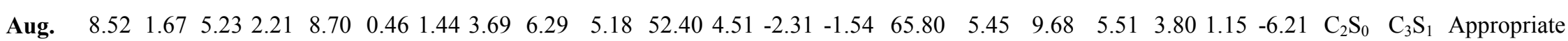

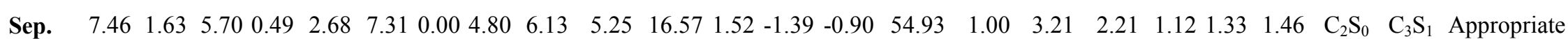

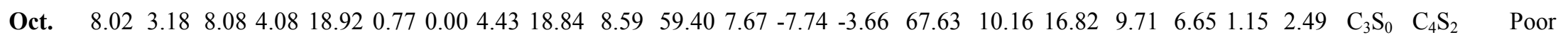

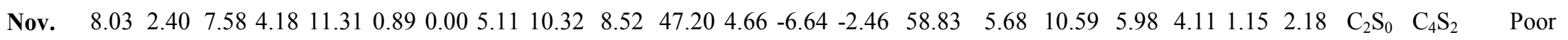

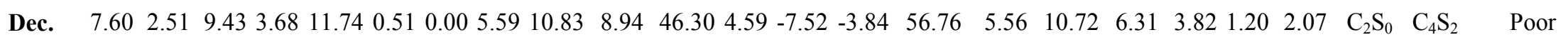

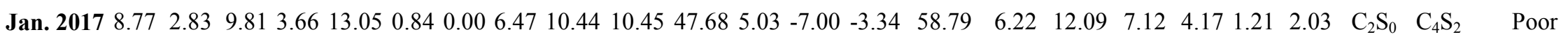

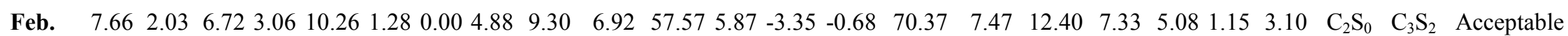

Mar. $\quad \begin{array}{llllllllllllllllllllllllllllllll}7.04 & 2.14 & 6.72 & 3.06 & 10.26 & 1.28 & 0.00 & 4.88 & 9.30 & 6.92 & 62.87 & 6.89 & -1.87 & 0.84 & 75.16 & 8.99 & 15.06 & 8.76 & 6.06 & 1.16 & 7.32 & \mathrm{C}_{2} \mathrm{~S}_{0} & \mathrm{C}_{3} \mathrm{~S}_{2} & \mathrm{Acceptable}\end{array}$

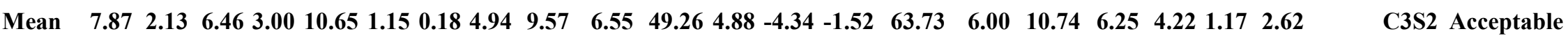

- Water quality class according to USDA (1954); $\mathrm{C}_{1}, \mathrm{C}_{2}, \mathrm{C}_{3}, \mathrm{C}_{4}$ are low, medium, high and very high salinity; $\mathrm{S}_{1}, \mathrm{~S}_{2}, \mathrm{~S}_{3}, \mathrm{~S}_{4}$ are low, medium, high and very high sodicity, respectively.

- SCAR : Sodium, calcium activity ratio $=\mathrm{Na} / \sqrt{ } \mathrm{Ca}$. in $\mathrm{mmolc} / \mathrm{L}^{-1}($ Gupta, 1984).

- ICAR: water quality class according to Gupta (1979 a;b); $\mathrm{C}_{0}, \mathrm{C}_{1}, \mathrm{C}_{2}, \mathrm{C}_{3}, \mathrm{C}_{4}, \mathrm{C}_{5}$ are non, normal, low, medium, high and very high salinity; $\mathrm{S}_{0}, \mathrm{~S}_{1}, \mathrm{~S}_{2}, \mathrm{~S}_{3}, \mathrm{~S}_{4}, \mathrm{~S}_{5}$ are non, normal, low, medium, high, and very high sodicity, respectively.

- PI: Permeability Index, ESP: Exchangeable Sodium Percentage, RSC: Residual Sodium Carbonate, RSB: Residual Sodium Bicarbonate, SAR: Sodium: Calcium Activity Ratio.
} 
Table 3. Mean values of dominant elements, some calculated indices, and classification for water samples collected from Batss drain from April 2016 to March 2017

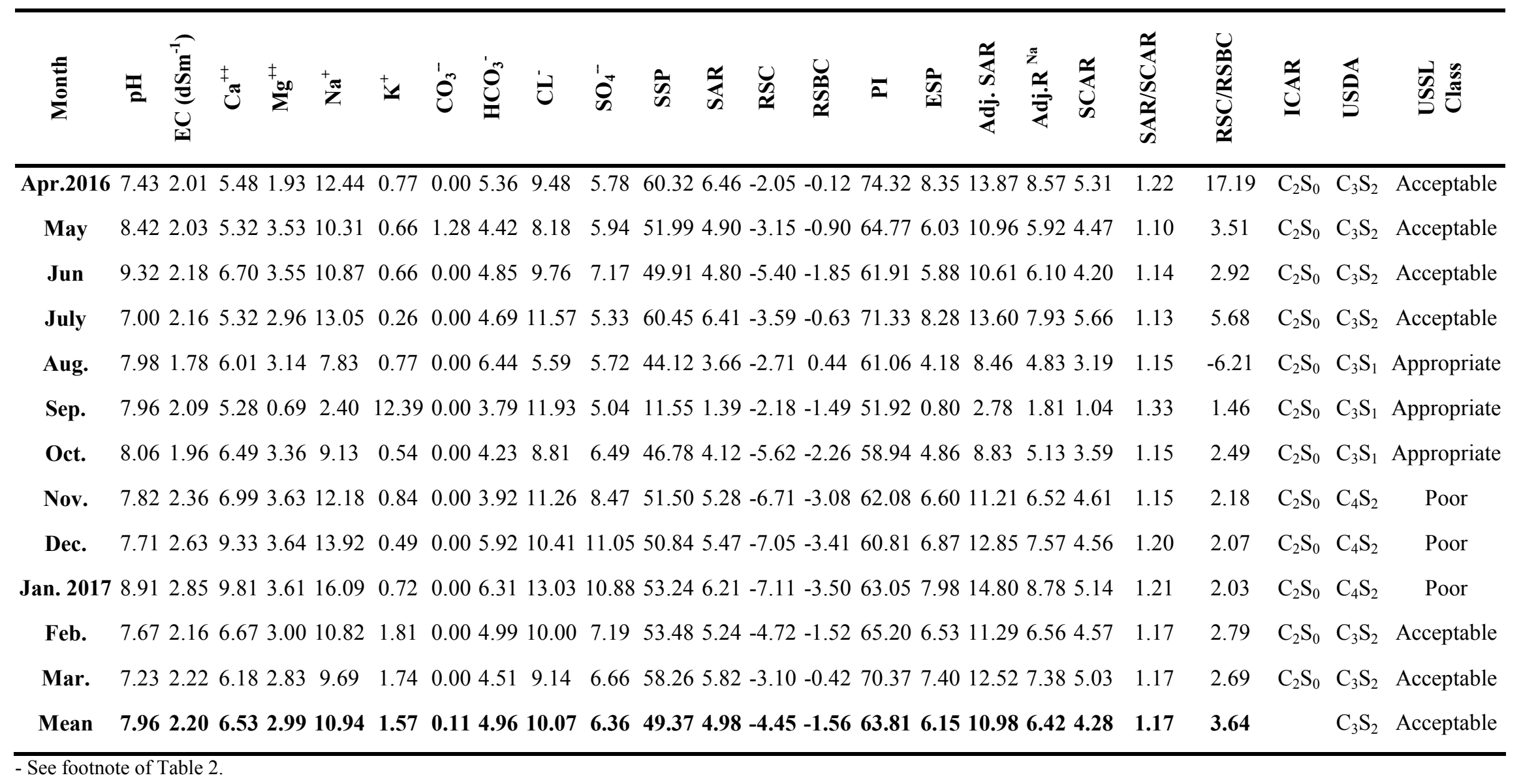


Table 4. Mean values of dominant elements, some calculated indices, and classification for water samples collected from El Gharq drain from April 2016 to March 2017

\begin{tabular}{|c|c|c|c|c|c|c|c|c|c|c|c|c|c|c|c|c|c|c|c|c|c|c|c|c|}
\hline 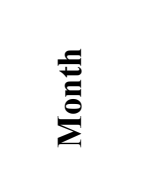 & $\frac{\pi}{2}$ & $\stackrel{\overbrace{}}{\tilde{1}}$ & $\underbrace{+\pi}$ & $\sum^{+000}$ & ${ }^{+} \boldsymbol{\pi}$ & \pm & '́n & $\overbrace{}^{\infty}$ & ن' & $\overbrace{}^{+}$ & $\hat{\infty}$ & $\underset{\mathscr{a}}{\mathscr{4}}$ & $\underset{\mathscr{N}}{\mathscr{\varkappa}}$ & 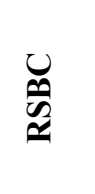 & $\bar{a}$ & $\hat{\bar{\Omega}}$ & 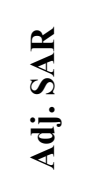 & $\frac{\pi}{2}$ & $\sum_{0}^{\mathscr{Z}}$ & 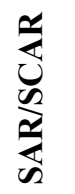 & 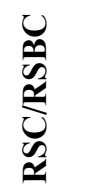 & $\underset{U}{u}$ & $\underset{\sigma}{\mathscr{a}}$ & $\begin{array}{l}\vec{n} \\
\tilde{\omega} \\
\tilde{D} \\
\bar{U}\end{array}$ \\
\hline Apr.2016 & 7.56 & 53.30 & 8.71 & 5.43 & 18.70 & 0.92 & 0.00 & 5.83 & 17.77 & 10.16 & 55.39 & 7.03 & -8.31 & -2.88 & 64.30 & 9.20 & 16.58 & 9.07 & 6.34 & 1.11 & 2.89 & $\mathrm{C}_{3} \mathrm{~S}_{0}$ & $\mathrm{C}_{4} \mathrm{~S}_{2}$ & Poor \\
\hline May & 7.45 & 4.58 & 10.07 & 6.44 & 28.49 & 0.77 & 0.00 & 7.29 & 27.65 & 10.82 & 62.25 & 9.91 & -9.22 & -2.78 & 69.31 & 13.50 & 24.56 & 13.10 & 8.97 & 1.10 & 3.31 & $\mathrm{C}_{3} \mathrm{~S}_{0}$ & $\mathrm{C}_{4} \mathrm{~S}_{3}$ & Very poor \\
\hline July & 7.00 & 5.37 & 12.29 & 8.01 & 32.62 & 0.72 & 0.00 & 8.49 & 31.74 & 13.41 & 60.82 & 10.24 & -11.81 & -3.80 & 67.15 & 13.98 & 26.59 & 13.80 & 9.31 & 1.10 & 3.11 & $\mathrm{C}_{4} \mathrm{~S}_{0}$ & $\mathrm{C}_{4} \mathrm{~S}_{3}$ & Very poor \\
\hline Aug. & 7.95 & 2.02 & 5.37 & 2.86 & 11.31 & 0.61 & 0.00 & 3.54 & 10.70 & 5.90 & 56.12 & 5.58 & -4.69 & -1.83 & 67.52 & 7.03 & 11.18 & 6.63 & 4.88 & 1.14 & 2.56 & $\mathrm{C}_{2} \mathrm{~S}_{0}$ & $\mathrm{C}_{3} \mathrm{~S}_{2}$ & Acceptable \\
\hline Sep. & 8.34 & 3.29 & 7.72 & 0.84 & 4.50 & 19.83 & 1.18 & 4.40 & 18.84 & 8.48 & 13.67 & 2.17 & -2.99 & -3.32 & 50.48 & 1.96 & 4.89 & 3.08 & 1.62 & 1.34 & 0.90 & $\mathrm{C}_{3} \mathrm{~S}_{0}$ & $\mathrm{C}_{4} \mathrm{~S}_{1}$ & Poor \\
\hline Oct. & 8.00 & 3.37 & 9.43 & 4.66 & 18.61 & 0.97 & 0.00 & 5.11 & 18.60 & 9.96 & 55.28 & 7.01 & -8.97 & -4.32 & 63.84 & 9.18 & 16.13 & 9.19 & 6.06 & 1.16 & 2.08 & $\mathrm{C}_{3} \mathrm{~S}_{0}$ & $\mathrm{C}_{4} \mathrm{~S}_{2}$ & Poor \\
\hline Nov. & 8.12 & 3.23 & 9.45 & 4.83 & 16.96 & 1.02 & 0.00 & 6.06 & 15.23 & 10.97 & 52.57 & 6.35 & -8.21 & -3.39 & 62.18 & 8.18 & 15.12 & 8.49 & 5.52 & 1.15 & 2.43 & $\mathrm{C}_{3} \mathrm{~S}_{0}$ & $\mathrm{C}_{4} \mathrm{~S}_{2}$ & Poor \\
\hline Dec. & 8.03 & 3.57 & 12.81 & 2.00 & 18.27 & 0.66 & 0.00 & 6.39 & 17.49 & 9.85 & 54.14 & 6.71 & -8.41 & -6.41 & 62.88 & 8.73 & 16.19 & 10.75 & 5.10 & 1.32 & 1.31 & $\mathrm{C}_{3} \mathrm{~S}_{0}$ & $\mathrm{C}_{4} \mathrm{~S}_{2}$ & Poor \\
\hline Jan. 2017 & 8.63 & 4.05 & 10.93 & 2.67 & 26.40 & 0.97 & 0.00 & 7.11 & 22.57 & 11.29 & 64.43 & 10.12 & -6.49 & -3.82 & 72.66 & 13.81 & 24.41 & 15.40 & 7.98 & 1.27 & 1.70 & $\mathrm{C}_{3} \mathrm{~S}_{0}$ & $\mathrm{C}_{4} \mathrm{~S}_{3}$ & Very poor \\
\hline Feb. & 7.72 & 3.08 & 9.94 & 4.38 & 20.24 & 2.73 & 0.00 & 6.11 & 20.60 & 10.46 & 66.86 & 9.38 & -4.89 & -1.84 & 75.46 & 12.70 & 19.97 & 11.83 & 8.05 & 1.18 & 2.14 & $\mathrm{C}_{3} \mathrm{~S}_{0}$ & $\mathrm{C}_{4} \mathrm{~S}_{3}$ & Very poor \\
\hline Mar. & 7.37 & 2.47 & 9.15 & 3.88 & 18.54 & 2.64 & 0.00 & 5.58 & 18.98 & 9.54 & 61.93 & 7.17 & -2.55 & 0.26 & 73.28 & 9.40 & 16.32 & 9.59 & 6.10 & 1.18 & 2.09 & $\mathrm{C}_{3} \mathrm{~S}_{0}$ & $\mathrm{C}_{4} \mathrm{~S}_{2}$ & Poor \\
\hline Mean & 7.79 & 3.58 & 9.34 & 4.14 & 19.84 & 2.35 & 0.10 & 6.01 & 19.89 & 9.42 & 55.09 & 7.53 & -7.36 & -3.33 & 66.13 & 9.95 & 17.80 & 10.25 & 6.45 & 1.18 & 1.27 & & $\mathbf{C}_{4} \mathbf{S}_{2}$ & Poor \\
\hline
\end{tabular}


Zagazig J. Agric. Res., Vol. 46 No. (6B) 2019

Table 5. Contents of trace elements and heavy metals in water of Bahr Wahby canal

\begin{tabular}{ccccccccc}
\hline Month & \multicolumn{7}{c}{$\mathbf{m g ~ L}^{-1}$} \\
\cline { 2 - 8 } & Cd & $\mathbf{C u}$ & $\mathbf{F}$ & $\mathbf{M n}$ & $\mathbf{Z n}$ & $\mathbf{P b}$ & $\mathbf{N i}$ & $\mathbf{B}$ \\
\hline Apr. 2016 & 0.00 & 0.00 & 0.00 & 0.01 & 0.00 & 0.21 & 0.00 & 0.00 \\
May & 0.00 & 0.01 & 0.08 & 0.00 & 0.00 & 0.00 & 0.00 & 0.00 \\
Jun & 0.02 & 0.15 & 0.71 & 0.15 & 0.00 & 0.04 & 0.03 & 0.00 \\
Jul & 0.00 & 0.00 & 0.00 & 1.00 & 0.00 & 0.00 & 0.00 & 0.00 \\
Aug. & 0.00 & 0.03 & 0.23 & 0.01 & 0.00 & 0.00 & 0.00 & 0.00 \\
Sep. & 0.00 & 0.05 & 0.11 & 0.03 & 0.00 & 0.01 & 0.00 & 0.00 \\
Oct. & 0.00 & 0.03 & 0.11 & 0.00 & 0.00 & 0.01 & 0.00 & 0.00 \\
Nov. & 0.00 & 0.04 & 0.01 & 0.00 & 0.02 & 0.01 & 0.00 & 0.21 \\
Dec. & 0.00 & 0.08 & 0.49 & 0.07 & 0.01 & 0.01 & 0.00 & 0.22 \\
Jan. 2017 & 0.00 & 0.01 & 1.41 & 0.11 & 0.02 & 0.00 & 0.02 & 0.00 \\
Feb. & 0.00 & 0.04 & 0.31 & 0.14 & 0.01 & 0.03 & 0.01 & 0.04 \\
Mar. & 0.00 & 0.04 & 0.31 & 0.14 & 0.01 & 0.03 & 0.01 & 0.04 \\
Mean & 0.00 & 0.04 & 0.31 & 0.14 & 0.01 & 0.03 & 0.01 & 0.04 \\
\hline
\end{tabular}

Table 6. Contents of trace elements and heavy metals in water of Batss drain

\begin{tabular}{ccccccccc}
\hline Month & \multicolumn{7}{c}{$\mathbf{m g ~ L}^{-1}$} \\
\cline { 2 - 8 } & $\mathbf{C d}$ & $\mathbf{C u}$ & $\mathbf{F e}$ & $\mathbf{M n}$ & $\mathbf{Z n}$ & $\mathbf{P b}$ & $\mathbf{N i}$ & $\mathbf{B}$ \\
\hline Apr. 2016 & 0.00 & 0.00 & 0.00 & 0.00 & 0.12 & 0.18 & 0.00 & 0.00 \\
May & 0.00 & 0.02 & 0.03 & 0.02 & 0.00 & 0.00 & 0.00 & 0.00 \\
Jun & 0.02 & 0.16 & 0.62 & 0.20 & 0.00 & 0.02 & 0.03 & 0.00 \\
Jul & 0.00 & 0.00 & 1.00 & 0.00 & 0.00 & 0.00 & 0.00 & 0.00 \\
Aug. & 0.00 & 0.02 & 0.12 & 0.01 & 0.00 & 0.00 & 0.00 & 0.00 \\
Sep. & 0.00 & 0.04 & 0.06 & 0.01 & 0.00 & 0.01 & 0.00 & 0.00 \\
Oct. & 0.00 & 0.02 & 0.10 & 0.00 & 0.01 & 0.01 & 0.00 & 0.00 \\
Nov. & 0.00 & 0.05 & 0.02 & 0.00 & 0.01 & 0.01 & 0.01 & 0.21 \\
Dec. & 0.00 & 0.11 & 0.42 & 0.10 & 0.01 & 0.00 & 0.00 & 0.22 \\
Jan. 2017 & 0.01 & 0.07 & 0.03 & 0.13 & 0.03 & 0.00 & 0.01 & 0.27 \\
Feb. & 0.00 & 0.05 & 0.24 & 0.05 & 0.02 & 0.02 & 0.00 & 0.00 \\
Mar. & 0.00 & 0.05 & 0.24 & 0.05 & 0.02 & 0.02 & 0.00 & 0.06 \\
Mean & 0.00 & 0.05 & 0.24 & 0.05 & 0.02 & 0.02 & 0.00 & 0.06 \\
\hline
\end{tabular}


Table 7. Contents of trace elements and heavy metals in water of El Gharq drain

\begin{tabular}{ccccccccc}
\hline Month & \multicolumn{7}{c}{$\mathbf{m g ~ L}^{-1}$} \\
\cline { 2 - 8 } & $\mathbf{C d}$ & $\mathbf{C u}$ & $\mathbf{F e}$ & $\mathbf{M n}$ & $\mathbf{Z n}$ & $\mathbf{P b}$ & $\mathbf{N i}$ & $\mathbf{B}$ \\
\hline Apr. 2016 & 0.00 & 0.00 & 0.00 & 0.01 & 0.00 & 0.21 & 0.00 & 0.00 \\
May & 0.00 & 0.01 & 0.08 & 0.00 & 0.00 & 0.00 & 0.00 & 0.00 \\
Jun & 0.02 & 0.15 & 0.71 & 0.15 & 0.00 & 0.04 & 0.03 & 0.00 \\
Jul & 0.00 & 0.00 & 0.00 & 1.00 & 0.00 & 0.00 & 0.00 & 0.00 \\
Aug. & 0.00 & 0.03 & 0.23 & 0.01 & 0.00 & 0.00 & 0.00 & 0.00 \\
Sep. & 0.00 & 0.05 & 0.11 & 0.03 & 0.00 & 0.01 & 0.00 & 0.00 \\
Oct. & 0.00 & 0.03 & 0.11 & 0.00 & 0.00 & 0.01 & 0.00 & 0.00 \\
Nov. & 0.00 & 0.04 & 0.01 & 0.00 & 0.02 & 0.01 & 0.00 & 0.21 \\
Dec. & 0.00 & 0.08 & 0.49 & 0.07 & 0.01 & 0.01 & 0.00 & 0.22 \\
Jan. 2017 & 0.00 & 0.01 & 1.41 & 0.11 & 0.02 & 0.00 & 0.02 & 0.00 \\
Feb. & 0.00 & 0.04 & 0.31 & 0.14 & 0.01 & 0.03 & 0.01 & 0.04 \\
Mar. & 0.00 & 0.04 & 0.31 & 0.14 & 0.01 & 0.03 & 0.01 & 0.04 \\
Mean & 0.00 & 0.04 & 0.31 & 0.14 & 0.01 & 0.03 & 0.01 & 0.04 \\
\hline
\end{tabular}

and 9.00, and that the most prevalent values of $\mathrm{pH}$ of Nile, drainage and sewage waters were $8.33,8.34$ and 8.46 , respectively. The $\mathrm{pH}$ tends to be buffered in soil and most crops can tolerate a slightly alkaline $\mathrm{pH}$.

\section{Salinity}

Electrical conductivity (EC) of water is related directly to the levels of ions dissolved in water (Wu et al., 2017). Classification of irrigation water with respect to salinity hazard, is primarily based on the development of salinity in the soil to extents that crop yields are adversely affected. Water analyses (Tables 2 and 3) shows that during 12 months, water had EC below $3.02 \mathrm{dSm}^{-1}$, and Table $4 \mathrm{EC}$ was $>3.0$. The mean values for the three water sites $(1,2$ and 3) were 2.13, 2.20 and $3.85 \mathrm{dSm}^{-1}$, (Tables 2, 3 and 4). Based on the classification of the USSL Staff (USDA, 1954), the water in sites 1, 2 could be classified as class $\mathrm{C}_{3}$ high salinity water with $\mathrm{EC}$ between 0.75 and $2.25 \mathrm{dSm}^{-1}$ (App. 1), whereas water of site 3 could be classified $\mathrm{C}_{4}$ (very high salinity water with EC between 2.25 and $5.00 \mathrm{dSm}^{-1}$ ). Based on the FAO guidelines (Ayers and Westcot, 1976) water of sites 1, 2 had EC of $0.75 \pm 3.0 \mathrm{dSm}^{-1}$, which indicates increasing problems, and site 3 could be classified with $>3.0 \mathrm{dSm}^{-1}$ which indicates severe problem (App.2). According to (Gupta, 1979b), water of sites 1, 2 could be classified as $\mathrm{C}_{2}\left(1.5-3 \mathrm{dSm}^{-1}\right)$, where water from site 3 could be as $\mathrm{C}_{3}\left(3-5 \mathrm{dSm}^{-1}\right)$.

\section{Sodicity}

Tables 2, 3 and 4 presents the result of sodium adsorption ratio (SAR) in water. The averages SAR at sites 1, 2 and 3 were 4.88, 4.98 and 7.53 , respectively. The water is of low sodicity hazards. According to USDA classification of irrigation water (App.1), the water could be classified as low sodicity class S1 $(<10)$.

Regarding the parameters of adjusted sodium hazards (Adj. ${ }^{\mathrm{R}} \mathrm{Na}$ ) proposed by Gupta (1979a), values ranged between 6.16 and 10.59 indicating low to high sodium hazards.

\section{Anions}

Anion contents in sites 1,2 and 3 averaged 9.75, 10.07 and $19.89 \mathrm{mmolcL}^{-1}$, respectively. Water with high chloride levels is usually 
considered polluted (Bikundia and Mohan, 2014). Chlorides could be released into rivers through ion exchange processes (Drever, 1997). Chlorides ranged between 4 and $10 \mathrm{mmolcL}^{-1}$ indicating no problem to increasing problems according to the FAO guidelines (Ayers and Westcot, 1976).

The average values of $\mathrm{HCO}_{3}{ }^{-}$in sites 1,2 and 3 were $4.49,4.96$ and $6.01 \mathrm{mmolcL}^{-1}$, respectively. According to FAO guidelines (App. 2), $\mathrm{HCO}_{3}{ }^{-}$ of $1.5-8.5$ indicate an increasing problem. The $\mathrm{pH}$ of the water sources ranged between 7.97 and 8.00 , indicating the ability to precipitate soluble calcium. Biocarbonate in water is derived from mineral and biogenic source. In biogenic formation, $\mathrm{CO}_{2}$ released in soil atmosphere, and therefore in the water draining through the soil, both directly by the microbial degradation of organic matter and from plant roots, dissolves in water to from carbonic acid which release $\mathrm{Mg}^{2+}$ and $\mathrm{Ca}^{2+}$ to the solution yielding $\mathrm{HCO}_{3}{ }^{-}$ (Maddock, 2008; Wu et al., 2017).

In all type of water bodies, sulphate is a naturally present ion in water (Wu et al., 2017). The average values of $\mathrm{SO}_{4}^{-}$in water samples from sites 1,2 and 3 were $6.55,6.36$ and 9.42 $\mathrm{mmolcL}^{-1}$, respectively. Sulfate might cause gastrointestinal irritation at higher levels in the drinking water (Marghade et al., 2013).

\section{Cations}

The results in Tables 2, 3 and 4 present the values of cations in waters. Average $\mathrm{Na}^{+}$in sites 1,2 and 3 were $10.65,10.94$ and $19.84 \mathrm{mmolcL}^{-1}$, respectively. High sodium may be related to pollutant (Wu et al., 2017). Average of $\mathrm{K}^{+}$in sites 1,2 and 3 were $1.15,1.57$ and 2.35 mmolcL ${ }^{-1}$, respectively. $\mathrm{K}^{+}$sources might include rain-water, potash fertilizer and weathering of potash silicate minerals. Average $\mathrm{Ca}^{+}$in sites 1, 2 and 3 were 6.46, 6.53 and 9.34 $\mathrm{mmolcL}^{-1}$, respectively. Some water samples from rivers might exceed the $\mathrm{Ca}^{+}$permissible limit of $10.0 \mathrm{mmolcL}^{-1}$ (Bikundia and Mohan, 2014). Average $\mathrm{Mg}^{+}$in sites 1,2 and 3 were 3.00, 2.99 and $4.14 \mathrm{mmolcL}^{-1}$, respectively.

\section{Micronutrients and Heavy Metals}

Results in Table 5, 6 and 7 show contents of micronutrients and heavy metals in water samples during the study period. Average contents $\left(\mathrm{mgl}^{-1}\right)$ of $\mathrm{Cd}, \mathrm{Cu}, \mathrm{Fe}, \mathrm{Mn}, \mathrm{Zn}, \mathrm{Pb}, \mathrm{Ni}$, and $\mathrm{B}$ in site 1 were $0.00,0.04,0.31,0.14,0.01$, $0.03,0.01$, and 0.04 , respectively. Comparable values in site 2 were $0.00,0.05,0.24,0.05,0.02$, $0.02,0.00$, and 0.06 , respectively. Those of site 3 were $0.00,0.04,0.31,0.140 .01,0.03,0.01$ and 0.04 , respectively. Ramadan (1995) and Mohamed et al. (1999) reported values rather similar to those of the present study. Heavy metals might contaminate surface water resulting in deterioration of water quality (Krishna et al., 2009). The heavy metals are severe pollutants owing to their toxic effects, persistence and bioaccumulative nature in the environment (Pekey et al., 2004). Accumulation of heavy metal in soil, leads to their adsorption or complexation by soil colloids and other soil component and can be leached into the groundwater either in ionic forms or soluble complex (Willems et al., 1981; Abdel-Aal et al., 1988).

On basis of US committee on water quality (Branson et al., 1975) presented in Appendix 4, waters of the three sources may be within the maximum permissible limits whether used continuously or used for of up to 20 years on heavy soils. Appendix 5 presents the modified six-class salinity-sodicity as USDA classification of irrigation water.

\section{Suitability of Waters concerning Salinity/ Sodicity}

According to the USDA (1954), water of site 1 was class $\mathrm{C}_{3} \mathrm{~S}_{2}$ (high salinity/medium sodicity). High salinity hazard $\left(\mathrm{C}_{3}\right)$ damage plants with low tolerance to salinity. Plants growth could be increased with excess irrigation for leaching or periodic use of low salinity water with providing good drainage. For sites 2 and 3, the class was $\mathrm{C}_{4} \mathrm{~S}_{2}$ (Very high salinity/medium sodicity). Very high salinity hazards $\left(\mathrm{C}_{4}\right)$ damage plants with high tolerance to salinity. Successful use as an irrigation source requires salt tolerance plants, good soil drainage, and excess irrigation for leaching and periodic utilization of low salinity water. Waters of sites 2, 3 can be used for irrigation of crop grown on coarse-textured light soils with fewer hazards than those grown on fine-textured ones. 
App.1 USDA Classification of irrigation water

\begin{tabular}{lcclcc}
\hline Salinity hazard & Class & EC $\left(\mathbf{d S m}^{-1}\right)$ & Sodicity hazards & Class & SAR \\
\hline Low & $\mathbf{C}_{\mathbf{1}}$ & $0.1-0.25$ & Low & $\mathbf{S}_{\mathbf{1}}$ & $10<$ \\
Medium & $\mathbf{C}_{\mathbf{2}}$ & $0.25-0.75$ & Medium & $\mathbf{S}_{\mathbf{2}}$ & $10-18$ \\
High & $\mathbf{C}_{\mathbf{3}}$ & $0.75-2.25$ & High & $\mathbf{S}_{\mathbf{3}}$ & $18-26$ \\
Very high & $\mathbf{C}_{\mathbf{4}}$ & $2.25-5.00$ & Very high & $\mathbf{S}_{\mathbf{4}}$ & $>26$ \\
\hline
\end{tabular}

App. 2. The FAO guidelines for interperation of quality for irrigation (Ayers and Westcot, 1976)

\begin{tabular}{|c|c|c|c|}
\hline \multirow[t]{2}{*}{ Irrigation problem } & \multicolumn{3}{|c|}{ Degree of problem } \\
\hline & $\begin{array}{c}\text { No. } \\
\text { problem }\end{array}$ & $\begin{array}{c}\text { Increasing } \\
\text { problem }\end{array}$ & $\begin{array}{c}\text { Saver } \\
\text { problem }\end{array}$ \\
\hline$\overline{\text { Salinity (affects crops water availability) } \mathrm{EC}_{\mathrm{w}}\left(\mathrm{dSm}^{-1}\right)}$ & $<0.75$ & $0.75-3.0$ & $>3.0$ \\
\hline Permeability (affects infiltration rate into soil) $\mathrm{ECW} \mathrm{dSm}^{-1}$ ) adj. SAR & $>0.5$ & $0.5-0.2$ & $<0.2$ \\
\hline Montmorillonite (2:1 crystal lattice) & $>6$ & $6-9$ & $>9$ \\
\hline Illite-Vermicultic (2:1 crystal lattice) & $<8$ & $8-16$ & $>16$ \\
\hline Kaolinite-sesquioxides (1:1 crystal lattice) & $<16$ & $16-22$ & $>22$ \\
\hline Specifice ion toxicity (affects sensitive crops) Sodium/adj.SAR) & $<3$ & $3-9$ & $>9$ \\
\hline Chloride (mmolc $\mathrm{L}^{-1}$ ) & $<4$ & $4-10$ & $>10$ \\
\hline Boron $\left(\mathrm{mg} \mathrm{L}^{-1}\right)$ & $<0.75$ & $0.75-2.0$ & $>2.0$ \\
\hline Miscellaneous effects (affects susceptible crops) $\mathrm{NO}_{3^{-}}$ & $<5$ & $5-30$ & $>30$ \\
\hline $\mathrm{N}$ or $\mathrm{NH}_{4}-\mathrm{N}\left(\right.$ mmolc $\left.\mathbf{L}^{-1}\right)$ & & & \\
\hline $\mathrm{HCO}_{3}\left(\right.$ mmolc $\left.\mathrm{L}^{-1}\right)$ (overhead sprinkling) & $<1.5$ & $1.5-8.5$ & $<8.5$ \\
\hline pH & \multicolumn{3}{|c|}{ Normal range $(6.8-8.4)$} \\
\hline
\end{tabular}

App. 3 Gupta's classification of water regarding salinity and sodicity (Gupta, 1979b)

\begin{tabular}{cccc}
\hline Class & Adj. SAR & Class & EC $\left(\mathbf{d S m}^{-1}\right)$ \\
\hline $\mathbf{A}_{\mathbf{1}}$ & $<10$ & $\mathbf{C}_{\mathbf{1}}$ & $<1.5$ \\
$\mathbf{A}_{\mathbf{2}}$ & $10-20$ & $\mathbf{C}_{\mathbf{2}}$ & $1.5-3$ \\
$\mathbf{A}_{\mathbf{3}}$ & $20-30$ & $\mathbf{C}_{\mathbf{3}}$ & $3-5$ \\
$\mathbf{A}_{\mathbf{4}}$ & $30-40$ & $\mathbf{C}_{\mathbf{4}}$ & $5-10$ \\
$\mathbf{A}_{\mathbf{5}}$ & $>40$ & $\mathbf{C}_{\mathbf{5}}$ & $>10$ \\
\hline
\end{tabular}


App. 4. Maximum concentrations of trace elements in irrigation waters, recommended by the US committee on water quality ${ }^{(a)}$

\begin{tabular}{|c|c|c|}
\hline \multirow[t]{2}{*}{ Element } & \multirow{2}{*}{$\begin{array}{c}\text { For waters used continuously } \\
\text { on all soils } \\
\text { mg L L }^{-1}\end{array}$} & \multirow{2}{*}{$\begin{array}{c}\text { For use up to } 20 \text { years on fine-textured } \\
\text { soils of pH } 6.0 \text { to } 8.5 \\
\mathrm{mg} \mathrm{L}^{-1}\end{array}$} \\
\hline & & \\
\hline Aluminum (Al) & 5.00 & 20.0 \\
\hline Arsenic (AS) & 0.10 & 2.0 \\
\hline Beryllium (Be) & 0.10 & 0.5 \\
\hline Boron (B) & 0.75 & 2.0 \\
\hline Cadmium (Cd) & 0.01 & 0.05 \\
\hline Chromium (Cr) & 0.10 & 1.0 \\
\hline Cobalt (Co) & 0.05 & 5.0 \\
\hline Copper (Cu) & 0.20 & 5.0 \\
\hline Fluoride (F) & 1.00 & 15.0 \\
\hline Iron $(\mathbf{F e})$ & 5.00 & 20.0 \\
\hline Lead (Pb) & 5.00 & 10.0 \\
\hline Lithium (Li) ${ }^{(\mathbf{b})}$ & 2.50 & 2.50 \\
\hline Manganese (Mn) & 0.20 & 2.0 \\
\hline Molybdenum (mo) & 0.01 & $0.05^{(\mathrm{c})}$ \\
\hline Nickel (Ni) & 0.20 & 2.0 \\
\hline Selenium (Se) & 0.02 & 0.02 \\
\hline Vanadium (V) & 0.10 & 1.0 \\
\hline Zinc (Zn) & 2.00 & 10.0 \\
\hline
\end{tabular}

(a) The levels will normally not adversely affect plants or soils.

No data available for Mercury (Hg), Silver (Ag), Tin (Sn), Titanium (Ti), Tungesten (W).

(b) Recommended maximum concentration for citrus is $0.75 \mathrm{mg} \mathrm{L}^{-1}$.

(c) Only for acid fine-textured soils with relatively high iron oxids contents (Branson et al., 1975).

\section{Conclusion}

Water characteristics of drains are affected by the nature, composition of soils from which the water was drained. In addition, good agricultural drainage network, good behaviour of the farmer not to overuse the pesticides, lakes, and human activities would affect the properties of drainage water of the area water of site 1 was class $\mathrm{C}_{3} \mathrm{~S}_{2}$ (high salinity/medium sodicity). High salinity hazard $\left(\mathrm{C}_{3}\right)$ damage plants with low tolerance to salinity. Plants growth could be increased with excess irrigation for leaching or periodic use of low salinity water with providing good drainage. For sites 2 and 3, the class was $\mathrm{C}_{4} \mathrm{~S}_{2}$ (Very high salinity/medium sodicity). Very high salinity hazards $\left(\mathrm{C}_{4}\right)$ damage plants with high tolerance to salinity. Successful use as an irrigation source requires salt tolerance plants, good soil drainage, and excess irrigation for leaching and periodic utilization of low salinity water. Waters of sites 2,3 can be used for irrigation of crop grown on 
coarse-textured light soils with fewer hazards than those grown on fine-textured ones.

\section{REFERENCES}

Abdel-Aal, Sh.I., R.R. Shahin, M.A. AbdelHamid and A.M. Abdel-Tawab (1988). Impact of liquid wastes of industrial complex at Helwan on water quality of both Nile and Canal streams. Egypt. J. Soil Sci., 28 (4): 421-432.

Allam and Allam (2007). Water resources in Egypt: Future challeges and opportunities; Water Int., 32 (2): 205-218.

Ayers, R.S. and D.W. Westcot (1976). Water quality for agriculture. Irrigation and drainage. Rev. 1 Food and Agric., organ. UN, Rome, 29.

Bikundia, D.S. and D. Mohan (2014). Major ion chemistry of the ground water at the Khoda Village, Ghaziabad, India. Sustain. Water Qual. Ecol., 3-4: 133-150.

Branson, R.L., P.F. Pratt, J.D. Rhoades and J.D. Oster (1975). Water quality in irrigation water sheds. J. Environ. Quality, 4: 33-40.

CAPMAS (2016). Central Agency for Public Mobilization and Statistics, Report.

Drever, J.I. (1997). The geochemistry of natural waters: surface and groundwater environments; prentice hall: Upper Saddle River, NJ, USA.

EEAA (2008). Egypt State of the Environment Report 2008. Egypt Environmental Affairs Agency, Cairo, Egypt. Available: ttp://www. eeaa. gov.e.g./ english/info/ report_search. asp\#soe.

El-Sherbieny, A.E., S.A. El-Saadany and F.A.A. Osman (1998). Seasonal variations in quality of some drainage water in Sharkia Governorate. Egypt. J. Soil Sci., 38 (1-4): 185-198.

FAO (2002). Food and Agriculture Organization, FAO Year Book, Production, 55, FAO, Rome, Italy, 16: 4-6.

Gupta, I.C. (1979a). Use of Saline Water in Agriculture in Arid and Semi-arid zones' of India. Oxford and IBH Publishing Co., Pvt. Ltd., New, Delhi, India.
Gupta, I.C. (1979b). Note on the effect of leaching and gypsum on the detoxieation of boron in saline-sodic soils. Curr. Agric., 4: 51- 55 .

Gupta, R.K., D.K. Bhumbla and I.P. Abrol (1984). Effect of sodicity, $\mathrm{pH}$, organic matter, and calcium carbonate on the dispersion behavior of soils. Soil Si., 137 (4): 245-251.

Jackson, M.L. (1958). Soil Chemical Analysis, Printice. Hall, Inc., New Jersey, USA.

Krishna, A.K., A. Satyanarayanan and P.K. Govil (2009). Assessment of heavy metal pollution in water using multivariate statistical techniques in an industrial area: A case study from Patancheru, Medak District, Andhra Pradesh, India. J. Hazard. Mater., 167: 366-373.

Maddock, I. (2008). Groundwater in the environment: An introduction, by Paul L. Younger, River Res. Appl., 24: 1377.

Marghade, D., D.B. Malpe and A.B. Zade (2013). Major ion chemistry of shallow groundwater of a fast-growing city of enteral India. Environ. Monit. Asses., 184 : 2405-2418.

Mohamed, L.R., A.E. Nasr-Alla and W.M. Mosad (1999). Evaluation drainage water quality in El-Gharbia Governorate, Egypt. J. Afr. Earth Sci., 134 : 56-72.

MWRI (2013). Water resources development and management strategy in Egypt - 2050. Cairo, Egypt: Ministry of Water Resources and Irrigation in Arabic Report submitted to: National Water Quality and Availability Management Project (NA WQAM), March 2007. DRI, NWRC, Egypt.

Pekey, H., D. Karakas and M. Bakoglu (2004). Source apportionment of trace metals in surface water of a polluted stream using multivariate statistical analyses. Mar. Pollut. Bull., 49: 809-818.

Ramadan, S.A. (1995). Heavy metals pollution in Manzala lake and the possibility of its water re-use. J. Agric. Sci. Mansoura Univ., 20 (10): 4501-4513. 
Shaban, Kh.A.H. (1998). Studies on pollution of some cultivated soils. M.Sc. Thesis, Fac. Agric., Zagazig Univ., Egypt.

Suarez, D.L. (1981). Relationship between pH and SAR and an alternative method for estimating SAR of soil or drainage water. Soil Sci. Soc. Ame. 1., (45): 469-75. Suitability of the soils South E1 Farafra Oasis, Western Desert, Egypt. Arab. J. Geosci., 6: 2313-2328.

USDA (1954). Diagnosis and Improvement of Saline snd Alkali Soils. United State Agric. Dept., (USDA) Hand Book 60.
Willems, M., B. Pedersen and J.S. Storgaar (1981). Accelerated leaching of some common and trace element from soil mixed with sewage sludge or sludge ash. Acta Agric. Scand., 31: 23-342.

Wu, T., X. Li, T. Yang, X. Sun, H.W. Mielke, Y. Cai, Y. Ai, Y. Zhao, D. Liu, X. Zhang (2017). Elements in source water (Drinking and Surfaces Water) within Five Cities from the Semi-Arid and Arid Region, NW China: Occurrence, Spatial Distribution and Risk Assessment. Int. J. Environ. Res. Public Health, 14: 1168.

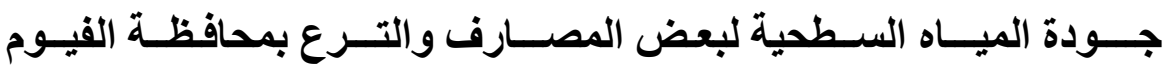

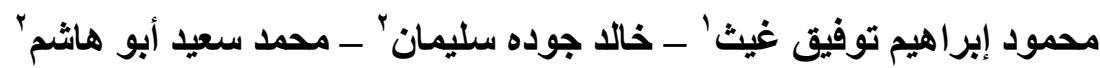

$$
\begin{aligned}
& 1 \text { ـ معهد بحوث الهيدروليكا ـ المركز القومي لبحوث المياه ـ مصر } \\
& \text { rـ قسم علوم الأر اضي _ كلية الزر اعة - جامعة الزقازيق ـ مصر }
\end{aligned}
$$

تم تجميع بم عينة مياه من ثلاث قنوات للري والصرف في محافظة الفيوم لتحديد نوعية المياه المستخدمة في هذه

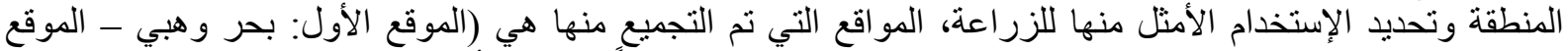

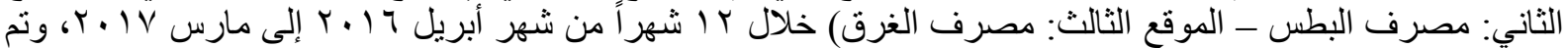

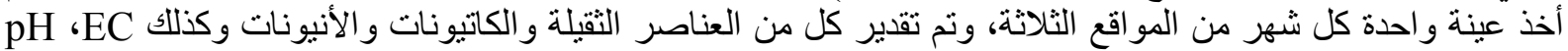

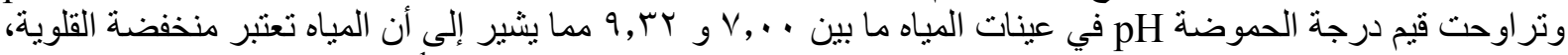

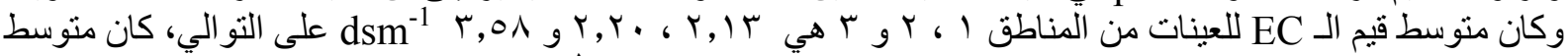

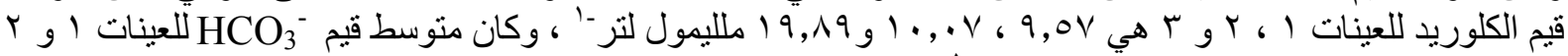

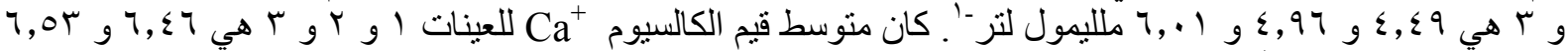

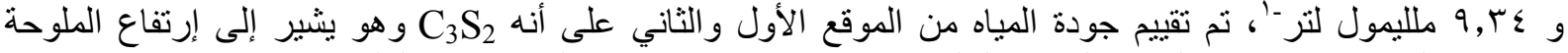

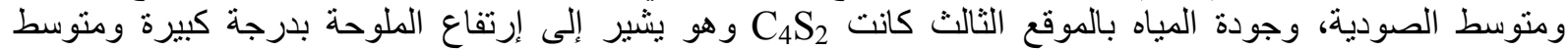

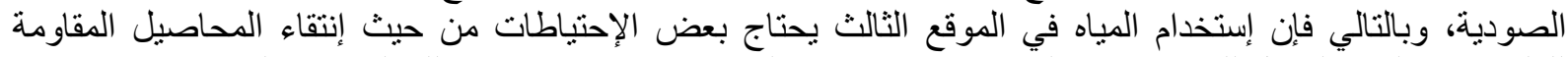
للملوحة وعمليات الغسيل للتربة وجودة الصرف بهان وهي وهى من الضروريات عند إستخدام تلك المياه في الزر اعة.

أستاذ الأر اضي المتفرغ - كلية الزر اعة بمشتهر - جامعة بنها. أستاذ ورئيس قسم الأر اضي - كلية الزر اعة الزعة - جامعة الزقازيق.
المحكمـــــون:

ا ـ أ.د. علي أحمد عبدالسلام ץ ـ أ.د. أيمن محمود حلمـي آدمد علدي 